\title{
PEDAGOGICAL RESOURCE OF FORMATION OF PROJECT TECHNOLOGICAL CULTURE FOR TEACHERS OF TECHNOLOGY
}

\author{
Slabko V. M., Makarenko L. L.
}

\section{INTRODUCTION}

To identify cultural-historical and pedagogical research resource of designed technological teachers' culture it is considered the theoretical works that model the real pedagogical concepts for development and justification of these models, for the sake of study of the secrecy of the approach to pedagogy, performed under the leadership of Nychkalo N. H. the work of Gineczinckij V. I. ${ }^{2}$, who first suggested treating pedagogy as a projection, introducing and analyzing the functioning of a pedagogical system with a special purpose. Examples of diligent elaboration of the theoretical models can be found in the work of Ball G. A. ${ }^{3}$, Sydorko V. P., Tverezovska N. T. ${ }^{4}$, Bereziuk O. S. ${ }^{5}$, Clactenyn V. A. ${ }^{6}$, Cerykov V. V..

All in one pedagogical cuts bring categorically fixed conceptual transitions through the theoretical models to practical testing. The purpose of such work is revealed in general and briefly focused in the central category, around which the synthesis of the theoretical ideas and practical methods occurs. The names of these same central categories are denoted and the corresponding theoretical models (B. Z. Vylfov, I. P. Ivanov, V. A. Kan-Kalyk, Kh. Y. Lyimetc, T. N. Malkovcka, A. V. Mydryk,

\footnotetext{
${ }^{1}$ Nychkalo N.H. Rozvytok profesiinoi osvity $\mathrm{v}$ umovakh hlobalizatsiinykh ta intehratsiinykh protsesiv: monohrafiia. - K.: Vydavnytstvo NPU imeni M.P. Drahomanova, 2014. - $125 \mathrm{~s}$.

${ }^{2}$ Gineczinckij V. I. Ocnovy' teoreticheckoj pedagogiki : ychebnoe pocobie. - CPb., 1992. $-325 \mathrm{c}$.

${ }^{3}$ Ball G. A. Teoriya ychebny’x zadach. - Mockva : Pedagogika, 1990. - 184 c.

${ }^{4}$ Sydorko V. P., Tverezovska N. T. STRUKTURA I FUNKTsII MIZhPREDMETNYKh ZVIaZKIV ॥ Visnyk Natsionalnoho universytetu oborony Ukrainy 5 (42) /2014. S. 157-161.

Bereziuk O.S. Metodyka poetapnoho upravlinnia protsesom modeliuvannia pedahohichnykh sytuatsii // Profesiina pedahohichna osvita: innovatsiini tekhnolohii ta metodyky: Monohrafiia / Za red. O. A. Dubaseniuk. - Zhytomyr : Vyd-vo ZhDU im. I. Franka, 2009. - S. 377-390. C. 36 .

${ }^{6}$ Clactenyn V. A., Podymova L. C. Pedahohyka: Ynnovatsyonnaia deiatelnoct. - Mockva : Mahyctr, 1997. -

${ }^{7}$ Cerykov V. V. Obrazovanye y lychnoct. Teoryia y praktyka proektyrovanyia pedahohycheckyx cyctem. Mockva : Lohoc, 1999. - 272 c.
} 
L. I. Novikova, N. F. Radionova, A. P. Triapitsyna, H. I. Shchykina etc.). We have been analyzed studies of interdisciplinary links in studies and integration of educational objects (Yu. I. Dik, V. N. Makcymova) work related to problems of choice of methods and pedagogical research and decision-making in real practice of learning and nurturing (Yu. K. Babanckyi, Z. I. Vacylieva, M. Ya. Vilenckyi, B. C. Hershynckyi, I. Ya. Lerner, C. A. Racchetyna, M. N. Ckatkina, O. V. Titova); numerical separate methods and cyclical tendencies of their generalization (I. P. Ivanov, V. A. Izvozchikov, A. H. Olneva); works related to the valuable aspects of pedagogical activity and pedagogical development, insofar as the value of the direct-technological culture is determined by the price criteria alone (C. H. Vershlovckyi, V. V. Horshkova, A. P. Triapitsyna).

In this way, in the pedagogical science there are serious grounds for general theoretical, systematic and methodological, analitic, value-oriented orders for the development of a methodological system for the formation of direct-technological filters. However, any attempts to link these heuristic frontiers as well-known theoretical estimates of formation and development of direct-technological filters haven't been worked out yet.

We revert to some of the centers of pedagogical practice, which testify about the necessity of justifying the phenomenon of direct-technological culture.

As early as in the 70's of the XX century, the students pointed to the pursuit of a component in the activity of a teacher. This is most pronounced in the work of Kyzmyna $N . V .^{8}$, where the specified component has been removed on the basis of sequential usage of the systematical approach.

Zahviazynckyi V. Y. ${ }^{9}$ draws more attention to heuristic, creative side of the future teacher's activity. In this case, the author, from one side, speaks about the necessity of rational reconstruction of the three-posterior

\footnotetext{
${ }^{8}$ Kyzmyna N. V., Hynetsynckyi V. Y. Aktyalnye problemy profeccyonalno-pedahohycheckoi podhotovky ychytelia // Covetckaia pedahohyka. - 1982. - № 3. - C. 63-66; Kyzmyna N. V. Ocherky pcyxolohyy tryda ychytelia: pcyxolohycheckaia ctryktyra deiatelnocty ychytelia y formyrovanye eho lychnocty. - Lenynhrad : LHU, 1967. - $184 \mathrm{c}$.

${ }^{9}$ Zahviazynckyi V. Y. Pedahohycheckoe tvorchectvo ychytelia. - Mockva : Pedahohyka, 1987. - 160 c.
} 
teacher and in this contact he mentions during projecting, but with another, - does not breed between the group of projecting, planning and projecting, sees in them a single flow of three-fold. Consequently, while pedagogical twist and practice are interrupted, according to the classification of Zahviazynckyi V. Y. at the level of improvement of the invention, it is unlikely that rational reconstruction of practical pedagogical activity is possible.

Until the mid-1980s, there was only one concept - "enforceable" correlating theory and practice, but from the beginning of the 80's onwards, innovative innovations initiated by teachers and innovators began to emerge (I. P. Volkov, E. N. Ilin, C. N. Lycenkova, V. F. Shatalov). In order to expand the experience of newcomers, the needs were revealed in the systematic review of the entire educational environment of the colored yacht. First of all, the practical needs revealed during the rational reconstruction of the work of newcomers have been pointed out by L. M. Frydman ${ }^{10}$.

The works that have emerged over the years have been the authors who came up with the idea of a wholly practically implemented pedagogical system. To this end, V. A. Karakovckoho and M. P. Shchetynina are identified as distinguishing the projective component of practical pedagogical activity as a self-directed type of activity.

It is important to note that innovative, practice-initiated learning experiences start with not just schools and not just learning. The higher needs of the higher school, both in the system of extracurricular and in the system of pupils, appeared in the projective needs.

The third aspect of the review of modern pedagogical activity is that it allows revealing the problems of pedagogical projection and project technological culture is social culture.

Evolution as a sphere of filters cannot be subjected to dynamic loads from the side of rapid-flowing and historical cultural and social-economic flows.

\footnotetext{
${ }^{10}$ Frydman L. M. Pedahohycheckyi opыt hlazamy pcyxoloha. - Mockva : Procveshchenye, 1987. - 224 c.
} 
Beginning in the 70s of the XX century, the researchers have pointed more strongly to the crises in the outbreak (F. H. Kymbc). In doing so, attention is drawn to the contradictions between the growing value of color and its underestimated social effect; between the formal receipt of a human being in the blossoming process of knowledge and the formation of a cultural, torsional and social responsibility, he contradiction between the traditional "strategy of preparation", which is the perfect work in the way of different stewardship of economic means, ecological terms and social structures, and blossom in fuller and deeper meanings of this word that reveals all the richness of person's potential that changes all the time. The researchers consider these contradictions to be global and dedicate a great deal of their work to them (K. Anhelovckyi, Dzh. Botkin, L. P. Byieva, V. P. Zinchenko, I. C. Kon and T. Khiucen)

Withdrawal of the indicated arguments is possible only in the way of a new prudent decision. The twentieth anniversary is differentiated by such an initiative in all worlds. The most prominent of them are the UNECCO Lifelong Education ${ }^{11}$ concept and the corresponding works on continuous evaluation of V. C. Vladyclavlieva, V. H. Onyshkina ${ }^{12}$ and Yu. N. Kyliutkina $^{13}$, B. C. Hershynckoho ${ }^{14}$ In the eightieth years of the twentieth century, new concepts of coloring appeared in the world. For example, in the USA, this is the report of the Gardner Comic and America 2000 ${ }^{15}$, Sweden - T. Khiucena ${ }^{16}$ project; in the CRCR - these are two alternative concepts, prepared by RASC "Base School" and the Presidium of the CCCR AES.

However, all of these initiatives had features that were only ecofriendly in terms of models of desired change. They need the right solution,

\footnotetext{
${ }^{11}$ ЮНЕСКО и развитие образования взрослых // Перспектива. Вопросы образования. - 1982. - № 1-2. C. $137-145$.

${ }^{12}$ Onyshkyn V. H., Kyliutkyn Yu. N. Neprerbvnoe obrazovanye - pryorytetnoe napravlenye nayky // Covetckaia pedahohyka. - 1989. - № 2. - C. 86-91.

${ }^{13}$ Kyliutkyn Yu. N., Cyxobckaia H. C. Modelyrovanye pedahohycheckyx cytyatsyi. - Mockva : Pedahohyka, 1981. -207 c.

${ }^{14}$ Hershynckyi B. C. Fylocofyia obrazovanyia: naychnыi ctatyc y zadachy // Covetckaia pedahohyka. 1991. - № 4. - C. 69-74; Hershynckyi B. C. Fylocofyia obrazovanyia dlia KhKhI veka: (V poyckax praktykooryentyrovannых obrazovatelnыx kontseptsyi) . - Mockva : Covershenctvo, 1998. - 608 c.

${ }_{15}^{15}$ America 2000: an Education Strategy. - V. S. Government printing office, 1991. - 66 p.

16 Khiucen T. Obrazovanye v 2000-m hody: yccledovatelckyi proekt ; per. co shved. E. M. Cokolova. Mockva : Prohrecc, 1977. - 343 c.
} 
the adjustment to it, but they move little constructive material, and they are not sufficient for practical realization, they do not have the necessary for revisions to the level of a specific educational system. At the same time, however, these works move to low cost points of departure for our study.

Each of the three recycle leads our problematic pedagogical projection and direct techno graphic filters. In each of these recirculations it is possible to concentrate, first and foremost, to be required in pedagogical projection as a separate activity and to cemiotic processes, secondly, the whole circle of consideration of the projecting and the direct technographic filters, and also the corresponding means and technologies.

Having set out to disclose the conceptual estimates of the formation of direct technological filters, we cannot get past the logical and methodological inevitability of the inverse to the generic concept of "projection", this will allow us to further integrate this conception into the general and cultural and cultural and historical experience of the emergence and formation of direct technological culture. We will act as soon as we develop to transform this situation into another, more acceptable", Caimon H. ${ }^{17}$ says, in a nutshell. It is not necessary to transform the quotations, to create complex objects and structures, to develop algorithms of actions, to plan stages of reaching a certain goal. The engineer is looking for ways to increase the efficiency with the device or more relevant material for the new contraction; the doctor determines if the patient has received assistance; economy develops a plan for the collapse of the enterprise; the manager is ready for his or her own injection; the politician creates programs of social transformations; the teacher selects materials for the future; after all, many of our daily schedules are planned for the next day (weeks, months, etc.).

All these actions have an intellectual character, these operations with signs, models. From the similar actions, there is a peculiar mechanism of the filtration solution, which lies in the evaluative phenomena of "projection". The action of mechanism is to inform the preparation of some changes, to the forefront of these changes.

${ }^{17}$ Caimon H. Nayky ob yckycctvennom. - Mockva : Myr, 1972. - 147 c. 
In our study, we emerge from the interpretation of the filter as a specific human activity ${ }^{18}$. Speaking of "activity", we see this system of supra-biological means of human activity ${ }^{19}$ that are revealed through the inclusion of humans in social cells. First of all, this system of flaws is volatile. With the change of material production, the development of the cynical forces of man, his self-realization, are changed and delineated by them. The person acquires the experience of a third activity, which is socially significant in its cynicism and aimed at the manifestation and change of the color in which the person lives. From these kinds of people, norms and values are created, which are then included in social memory. Reflection of a distinct lineage of information that "superimposes" over a genetically predetermined one is transmitted through social relations ${ }^{20}$.

Speaking about filters, we cannot mention the characteristics of organizational types corresponding to its historical stages, which B. A. Нікітін ${ }^{21}$ is specialized in; corporative-remicnichy (sample and recipe of his opening); professional or scientific (theoretical knowledge and text formats) and direct-textual (projects, programs, and technologies).

The researchers ${ }^{22}$ distinguish between canonical and direct-technological filters, distinguishing between the applied pre-existing texturizes and the present-day ones, as it begins, starting with the Renaissance epoch, cyclical cells, the exact technological nature by its meaning.

In archaic culture, the phenomena and the practical actions of the mycelium as one whole: the idea passed the action, the action created the ground for the emotional phenomena. Then, in the old Egyptian and Shimmering-Babylonian culture, the manifestations of the phenomena

\footnotetext{
${ }^{18}$ Arnoldov A. Y. Teoryia kyltyry: Yctoryzm y voprocy metodolohyy // Kyltyra, chelovek y kartyna myra. Mockva : Nayka, 1987. - C. 5-27; Эkolohyia cheloveka: ocnovnye problemy. Cbornyk naychnyx trydov. Mockva : Nayka, 1988. - 222 c.

19 Эkolohyia cheloveka: ocnovnye problemy. Cbornyk naychnyx trydov. - Mockva : Nayka, 1988. - 222 c.;

${ }^{20}$ Cemenova N. N. Nayka kak yavlenye kyltyry // Nayka y ee mecto v kyltyre. - Novocybyrck : Nayka, Cyb. otdelenye, 1990. - C. 51-58.

21 Nykytyn V. A. Orhanyzatsyonnye typy covremennoi kyltyry : avtoreferat doktora kyltyrolohyy : 24.00.01 - teoryia kyltyry. - Toliaty - Mockva, 1998. - 49 c.

${ }_{22}$ Kantor K. M. Opyt cotsyalno-fylocofckoho obъiacnenyia proektnyx vozmozhnoctei dyzaina // Voprocy fylocofyy. - 1981. - № 11. - C. 84-97; Nykytyn V. A. Orhanyzatsyonnye typy covremennoi kyltyry : avtoreferat doktora kyltyrolohyy : 24.00.01 - teoryia kyltyry. - Toliaty - Mockva, 1998. - 49 c.; Novykov A. M., Novykov D. A.»Metodolohyia. - Mockva : CYNTEH, 2007. - 668 c.; Cydorenko V. F. Henezyc proektnoi kyltyry // Voprocy fylocofyy. - 1984. - № 10. - C. 86-99.
} 
begin to detract from practical action. However, all kinds of ancient human activity have been inextricably linked to myth as a distinctive worldview. Mythological information is not intersecting natural and patchy, alive and inanimate. This is the only place where there is no boundary between the possible and the effective. From one side, these are transformed, converted, but still reflect the activity, and from the other - the reduction of moral norms, regulative practice. Myth is the canon of activity. Canon is a guarantee of the effectiveness of every case. Any projective actions - these are not very specific operations on the initial material, but also some action, complete ritual idea connected through myth space with outer space. Every action is a corollary to a single whole of rational moments and irrational experiences. Myth is a peculiar kind of worldview, specific, figurative, sensual, syncretic manifestation of the phenomena of nature and cyclic life ${ }^{23}$. Myth is the expressed knowledge of the world in the epoxy of mythological thinking ${ }^{24}$. Myth was the real space in which the scattering of the mind and action of man. Thus, in the myth, one can see the origin of the cell on the transformation of human phenomena through the final product of their actions and efforts, and also through the completion of the operation. So, there are reasons to speak about the exact function of the myth, which is hidden in the canonical filter ${ }^{25}$.

At times of antiquity, the attitudes toward myth are gradually changed as to the dominant form of cyclopic consciousness. For the sake of rational estimation of mythical materials, mycillites were taught to abstract, logically.

There is a gradual difference from the mythological explanations and images and the formation of the philo-sophistic thinking style, based on the rational marking. The most important achievements of the ancient Greek philosophers include: the ability to soak in concepts, to exert them, and to cure them in the plane of "pure thought". In this way, it is possible to remove the rational reasoning from the canvas of practical experience. In

\footnotetext{
${ }^{23}$ Keccydy F. X. Ot myra k lohocy. - Mockva : Mыcl, 1972. - 198 c.

${ }^{24}$ Holocovker Ya. Э. Lohyka myra. - Mockva : Nayka, 1987. - 218 c.

${ }^{25}$ Acmolov A. G. Pcixologiya lichnocti. - Mockva : MGU, 1980. - 367 c.
} 
culture, practice and scientific knowledge already belong to two-level, principally different, logical actions, and where complex problems of their interrelation arise. Aristotle in "Metaphysics" writes about the fact that, in fact, the purpose of knowing knowledge is icine, and the purpose of knowledge, which is developing activity, is the right: after all, people are active even then, when they consider things, what they are, they do not come forever, and things in her relationship are now and then. It is there that we find valuable and valuable breeding of science and practice. In the mind of Aryctotel, he who holds the art [is considered] wiser than he who has the nerve, the sitter - the wiser than the artisan, and the arts are beyond $\operatorname{sight}^{26}$. It is important to emphasize that the "vertical" scale of values is assigned, if the "knowledge of reasons" is higher than the "ability to act" and the "knowledge, not reversed to gain benefits", is higher than the need for "beyond".

The "people of nature", the artisans, considered their activity as a kind of art, enshrined in the Greek notion "techne". A combination of "techne" and a combination of natural and pragmatic, pragmatic and ethical in it. The works are "techne". According to the statements, the "techne" cannot be transmitted from person to person without direct access. The transmitted may be the knowledge of either, as obtained in the result of "techne". The "techne" is typed, passed through, through a practical imitation. Responses of similar convictions came to us in the form of English type tenses: "A blacksmith has no need of an axe".

The Middle Ages are becoming an epoch of canonical culture. The world is a harmonically organized unity, and in this whole unity there could not be any corporeal change. At that moment, re-activation restores the unity of knowledge and actions and measures to the extent that the restoration of the filter is more and more cynical.

Such language is authoritarian. The recipe does not have an author. The author is a tradition that is slowly composing, a fourth-rate evolution, gradually becomes valuable. "Yes, so", "so accepted," "so right,"

\footnotetext{
${ }^{26}$ Arictotel. Cochynenyia v chetyrex tomax. - Tom 1: Metafyzyka / red. V. F. Acmyc. - Mockva : Mycl, 1975. $-550 \mathrm{c}$.
} 
"so appropriate". he beginning of the destruction of the median canonical filter begins in the Renaissance epoxy. People began to become interested in the fact that the objective reality was not about themselves. The objects of work are perceived as things that are not capable of being transmitted by nature itself. There is an idea that a person may not match the sample but create the sample. Yes, God has touched man, faith is knowledge, divine will - the laws of the New Hour science. Renaissance - these are the assertions of new values: individual liberties, threefold, initiatives. It asserts the human right to the transformation of the world, to the enjoyment of authorship ${ }^{27}$.

The destruction of the canon begins from the moment when a person begins to look at nature, removed as a painter, who paints paintings, on his own. New cognitive attitude of the person to the world arises when the person finds "It is possible to come out of the world, if it has become one, to go outside, in order to view this world without you, in that form, which is not purified by its adherence" 28 . The creation of the "picture of the world" is the first stage in the formation of direct technological culture. It is necessary to understand clearly that the right is always implicitly implicit, in the latent state. The project turns out to be, so to speak, fused with a valid substantive transformation ${ }^{29}$. With the appearance of perspective painting, the appearance of a person in the outer world originates from its subjective phenomenon and thus eliminates from the person, the objectivity in the image. Therefore, the manifestation of a person can be translated into the plan of material manifestation and alone in this semiotic plan can be consideration, correction, imprisonment, at one and the same time, the framework of this entirety were clearly divorced programs of scientific theoretical and subject practical practice. Cognition at this distinction as one's gaze, and the theoretical pursuit were reduced to the universal harmony of the harmonious being real. In the substantive and practical activity, the medieval tradition rigorously identified the notion of

\footnotetext{
${ }^{27}$ Locev A. F. E'ctetika Vozrozhdeniya. - Mockva : Ickycctvo, 1978. - 495 c.

${ }^{28}$ Axytin A. V. Ponyatie "priroda" v antichnocti i v Novoe vremya. - Mockva : Nayka, 1988. - 208 c.

29 Kolmogorova L. C. Vozractny'e vozmozhnocti i ocobennocti ctanovleniya pcixologicheckoj kyl'tyry' shkol'nikov : dicc. ... d-ra pcixol. nayk. - Mockva, 2002. - 425 c.
} 
"know" and "be able to do". In this activity, the question is "how to do?" And there is no room for the question "why?".

Researchers point out certain object features of the canon of domainspecific (rhemic) activity ${ }^{30}$. Let us precede this recipe, expressed in a short description of the types "take", "stock", "measure", "endure". The recipe is not a project of practical activity, but a canonical model of activity, a projection of magical knowledge. There is point for doubt in it. The truth is one, it is augmented by the commonalities of mankind, anchored in the canon. The recipe is an element of mythological thinking, and "the myth was not knowledge but life, it was not studied, but in it we lived, in it (or by it) we were misled"31. The canyon is also inextricably linked to the recipe. Any recipe is a sacrilege, a mystery, some intrinsic value. This target is sacral, sacred, and is not subject to analysis, parsing, that is, only possible to follow and to follow. This is precisely related to the automaticity of execution. Receptive knowledge was stored in the smallest detail and then in the exact, according to the given "scenario", was opened. The script left no room for reflection. The very idea of the reflection is alien to the canon. It was perceived as a sin, an apostasy, she caused social sanctions, this dislike, for her. Finally, the canon is a distinctive sign system in which the recipe is coded and its rules, norms, and prohibitions associated with it. But this system is dogmatic, and only one value is assigned to it. Such a language can only be answered with certain specific questions, but in no case should it be asked new ones with the subject itself. Speaking at the origin of the projection, the students emphasize that the first projectors were "engineers-engineers",32, but "the picture reveals the nature",33.

\footnotetext{
${ }^{30}$ Goroxov V. G. Znat', chtoby' delat'. Ictoriya inzhenernoj profeccii i ee rol' v covremennoj kyl'tyre. Mockva : Znanie, 1987. - 176 c.; Gycev C. C., Gyceva E. A.»Vzaimodejctvie poznavatel'ny'x proczeccov v naychnom i texnicheckom tvorchectve. - Leningrad : Nayka, 1989. - 128 c.; Rozin V. M. Cpeczifika i formirovanie ectectvenny'x, texnicheckix i gymanitarny'x nayk. - Kracnoyarck : Izd-vo Kracnoyarckogo yn-ta, 1989. - 200 c.; Kharitonovich D. E'. Izobretatel'ctvo i rannie formy' inzhenernoj deyatel'nocti // Voprocy' filocofii. -1985 . - № 2. - C. 91-102.

${ }^{31}$ Kharitonovich D. E'. Izobretatel'ctvo i rannie formy' inzhenernoj deyatel'nocti // Voprocy' filocofii. 1985. - № 2. - C. 91-102.

${ }^{32}$ Goroxov V. G. Znat', chtoby' delat'. Ictoriya inzhenernoj profeccii i ee rol' v covremennoj kyl'tyre. Mockva : Znanie, 1987. - $176 \mathrm{c}$.

${ }^{33}$ Axytin A. V. Ponyatie "priroda" v antichnocti i v Novoe vremya. - Mockva : Nayka, 1988. - 208 c.
} 
The overcoming of the canon begins, when dismemberment is active, that is, the reflection of the separation and the information of the manufacturer of the same image produced. First of all, such distinctions are made with the period before the mass replication of these or other actions, which are significant in terms of their social results. The product of such action is significant in itself, is removed from the contact of the canon, and leaves its precious sacralized area, it loses its "creative individuality", including "neutral in valuable material production" 34 . Insofar as only the substantive-perforating activity (in a wide variety) becomes a mass, even if the value of this activity can be "excused by the barrel", they appear as a precursor for transferring the attention from the value of this activity to its technology $y^{35}$. In the case of technogenic approach, in the center of gravity, the axiom of the object-conversion activity is determined as the activity of the active. In the neutral medium of material production, various transformations of the filtered sample, which were previously neglected in the can, are possible. These transformations are based on the same line: change of technology (change of recipe), change of designation, touching and squeezing the skin tight, preserving only the traditional form of the activity of activity, which is a necessary for successful social and cultural activity. Texting leads to the delimitation of the functions of an earlier single activity entity. In the process of disaggregation in the operation, the activity of the entity is further reduced to the interaction of the generalized forces and factors. There is a similar methodological characterization characteristic of the technical sciences, in which the main is the knowledge of all their subjective-conversion activities.

From the moment of excision, the technologic approach as a means of elevation of the preoccupation of the object-conversion activity. Accordingly, there are also means of projecting. The most ancient can be considered: the present equivalence or economic projection, the organizational projection and the technical projection. An economic

\footnotetext{
${ }^{34}$ «Khill P. Nayka i ickycctvo proektirovaniya: metody’ proektirovaniya, naychnoe obocnovanie reshenij. Mockva : Mir, 1973. - 264 c.

${ }^{35}$ Khill P. Nayka i ickycctvo proektirovaniya: metody' proektirovaniya, naychnoe obocnovanie reshenij. Mockva : Mir, 1973. - 264 c.
} 
projection arises in connection with the necessity to anticipate the effective purpose of a substantive-conversion activity, to prevent costs and benefits $^{36}$. Organizational projecting has to do with the necessity of resolving the magnitudes; the initial priority is a momentary and technical problem, until the decision is made as to the large number of contractors whose forces should be directly directed. In the further development of production, there is a need for the distribution and coordination of production facilities, and also the integration, the integration of the former, the production, if there were also problems with organizational design. It can be said that the class-lesson system is a technological solution to the problem of organizing projection. Finally, the techno- logical projection gives it the power of saving the form and the underlying relationship (morphology) of the project, to consider variants of models of technology with the view of their effects, speeds of production, simplicity and others.

At the stage of excision, the projection as self-activity emerges and the specific - cymotic (signs) - means of this activity. In the midst of these tools, a distinctive role of the drawing, perspective painting, is distinguished.

The method of visualizing a problem, changing its vision is the old method of projecting. A. B. Ахутін points to the double role of the picture as a mediator between the man and the object of his activity. From one side, the painting seems to yank out people from the world and give them the ability to analytically dissect the depth plates. In this case, everything must be real, visible on the plane. Secondly, the picture replaces ambiguous words when the human phenomena are objectified.

In this way, the first phase of the appearance of a direct-technographic filter, its separation from the canonical flax became a techno- logical phase. In the center of attention, the substantive structures of practice are terminated, and, accordingly, the activity of their development and organization is determined. Traditional understanding of a project, if it was earlier in the text, in the case of other things, is a cyclical document for the

\footnotetext{
${ }^{36}$ Cheshev V. V. Vzaimocvyaz' inzhenernoj deyatel'nocti i naychnogo znaniya // Voprocy' filocofii. 1986. - № 3. - C. 53-60.
} 
creation of any kind of objects ${ }^{37}$. At the change came the modern understanding of the project as a complete cycle of the projective activity: the individual, the team, the organization, the company and the company. Every project from the emergence of an idea to the fullest completion brings about a number of stages of its own development. Complete cycles of development stages represent the life cycle of the project. It is customary to divide the life cycle into phases, phases into stages, and stages into stages.

It is natural that any project realizes a certain cyclicality of technologies. The most important role in the organization of a proactive activity is played by reflection - a thorough analysis of the goals, tasks of the project, results, etc.

In this way, the beginning of the formation of direct-technological filters of the future will be read by the technologists and can be won in the $\log$ of the category of the project on the basis of the triplet of the phases of the project: the projecting phase, the technological phase, the reflection phase. From this position, we hold on to our research, and we will consider the relevant phases in the course of practical activity. Understandably, such a division is quite common.

Concepts for the text-to-text filter are the key concepts: text, text, and reflection. In this case, two of them are seemingly opposite: the project (long - closed forward) and the reflection (long - reversed).

For any practical activity, the first phase - projecting - will have the same concepts and principles. Although it is understandable that in each of the specific cases, depending on the profession, there is a possibility for the activity, the opportunity to have the quality of the worker is possible.

The logic of the second phase - the technologic - it is determined by the content of each specific practical activity, which is determined exactly by the by a unique facsimile every now and then in totally different sets of conditions.

\footnotetext{
${ }^{37}$ Novikov A. M., Novikov D. A. Metodologiya. - Mockva : CINTEG, 2007. - 668 c.
} 
The third phase - the reflection phase - as well as the projection phase, is unambiguous and can be described in a unified way for any practical activity of the concept and structure.

The processes develop by the help of the creation of such a structure, in which the known mutual interactions are again realized with greater efficiency and interoperability. There is a technological thinking associated with the division of the operations inside the whole, their standardization and repetition. Adequate language translation is appeared. At the same time, the whole canon is being disturbed. It develops a polarity of rational and valuable aspects in the project.

On the textual phase of the canyon's distortion, the directtechnological thinking leaves behind the usual images of objects, fixed sets of standard shapes ${ }^{38}$. The author's use as a valuable word of directtechnology lies in the technological innovation. The object of the projection is to identify, in the first place, all the ways of creation determine the traditional objects. However, with the development of these means, the expansion of the world of artifacts, a person's right view is more and more imprinted, and an image of an object, their morphology and end. There is a variety of subjects that do not go beyond accepting functional relationships.

The contractive phase as a continuous phase of canyon distortion is even greater than the gap between the sensory and the precipitating sites. Creating a form leads to the creation of a rich second nature, farther from the natural. In this second nature, one has its own relations and laws, giving birth to new human needs, far from natural, one's own aesthetics. However, traditional types of functions will still be preserved. In this phase, the practical as a way of human endeavor enriched with new methods of direct-techno logical thinking, various modeling methods, different methods of refining, endpointing, etc.

During this period, the state of formation of the methodological methodology is reflected, which has fixed the rational aspect of the

\footnotetext{
${ }^{38}$ Gycev C. C., Gyceva E. A. Vzaimodejctvie poznavatel'ny'x proczeccov v naychnom i texnicheckom tvorchectve. - Leningrad : Nayka, 1989. -128 c.
} 
projection. It is revealed that the causal description of the phenomena is the only knowledge in the natural-natural way of understanding - it is not the only object of the intellectual activity of man. No less important and valuable concept of intellectual activity may be knowledge in its pure form, but prescriptive. Knowledge and requirements also require a variety of evaluation criteria. For the sake of knowledge, this is "truth - not true." The prescripts also evaluate the preceding measure as they correspond to the given task and the final results, and the results, also, they can be scattered by the parameters of optimality, economy and the like. From this historical stage, the differentiation of cyclic needs for knowledge and prescription begins.

For science and methodology, questions arise about community and differentiation of study and projection, about their valuable cooperation, and about their interaction. Historical announcements of the stages of occurrence of projection are denoted in the annulus by the largest and most common ones. At the early stage of the formation of direct-technocultural filters, the deletion of rectification as a separate activity constitutes a definite approach to this activity, which is traditional ${ }^{39}$.

Historically, it is the traditional approach that is focused on the object of projection. In this case, the self-priming projections are less wellknown. According to the traditional approach, the rigorous manifestation is without any changes in the projection technology. The magnitude of such a large number is determined by the number of variants of the projected objects. The projection technologies themselves, in this case, flash invisibly from the respective projection objects, which "derive" from the specifics of these objects.

The three-way approach leads to the case of the set of residuals - the closed set of the sequences of the formation of the second one to the second one. The one-sided attribution of the classical project is one-dimensional, one-and-a-half determinism of classical Newtonian mechanics. The ideal of classical learning - the ideal of cyber-objectivity - is a reflection in traditional design as well. A clear separation of the created object, from one side, and the

\footnotetext{
$172 \mathrm{c}$.

${ }^{39}$ Gacparckij V. Prakceologicheckij analiz proektno-konctryktorckix razrabotok. - Mockva : Mir, 1978. -
} 
adjusting, milling, forming object, from the other - is a very bright line. This type of design results in a thorough deletion of the projection of the all of the projectors, the refusal of reflection is only the beginning of the projection, the unambiguous nature of the precepts ${ }^{40}$.

Traditional projection was a successful development until that moment, until the existing type prototype was exhausted.

Effectively, for the traditional approach, it is only possible to project a specific one: the subject, principle, structure - whose functions are known (in each case, the common word), and therefore the created objects "fit" in the corresponding cells. The traditional projection is in line with the "further development" strategy. It is effective for the realization and concretization of well-known goals.

The (traditional) projection was viewed as isolated, delimited by the creation of the object that was suspended; that is, it was such that it did not emerge beyond the creation of objects, projections, structures, and with the above given functional characteristics. But if any pragmatic decision should be considered not isolated, not by itself, but as a link of possible future, directed to the future, it is lost. An unconventional project is always a complex task, the solution of which is impossible without taking into consideration a social and cultural context of this problem. Changing the functions of any system is obligatory, in principle it affects the performance in the method. (Unfortunately, changes in metasystem can be undetected, have a controllable character, and do not appear to accumulate a critical level of these changes. This creates the illusion of the possibility of an isolated solution of the problem with a problem in a subsystem, but early or late a critical level of change can be reached and reflected. Illusory isolation of the right tasks and, accordingly, the approach to them on the basis of the traditional projection is threatened by grave consequences). The basic complex approach of a simple task of unconventional projecting determines the new style of a straightforward technological activity, in which one and the same social, cultural, technical and organizational constituents interact and complement each other.

\footnotetext{
${ }^{40}$ Born M. Fizika v zhizni moego pokoleniya. - Mockva : Izd-vo inoctrannoj literatyry’, 1963. - 535 c.
} 
Accordingly, when the projections are formed, there is a non-nominal interaction of the states and approaches of different ways, their mutual enrichment and complementarity. The projection appears as a distinctive sphere of the cultural-historic creativity, where the "information about the world transforms itself into the following future activities ${ }^{41}$. It is fundamentally important that while considering the specific features of another object or entity, and concentrating on the internal law of direct and technical activity without direct specific character of the object being projected. There are many literatures, where such a framework is described by problems of non-conventional design ${ }^{42}$. Dzh. K. Dzhonc goes a long way in affirming the cynicism of his position, when he clarifies that the methods of projection are intended for the projection of anything, for the development of all citation in general, having on the basis of function and the use of things, the system in which they enter, or the centers in which they function $^{43}$. The analysis of the literature gives an opportunity to conclude that, until the 20th century of the century of projection, it is identified as an independent co-culture phenomenon. Precise-technological activity of the constituent as an individual, very limited and characteristic not only in engineering and business, but also in non-traditional galaxies, where its objects are both words and new objects, information centers, systems of activity. In this way, a straightforward technological culture that has emerged from a fractured canonical culture, appealed to the nonarticulated whole and the canopy of the canon of freedom, the authorship, the reflexive text, gradually came to the idea and methods of unconventional projection as a new level of reunion.

Concepts for the text-to-text filter are the key concepts: text, text, and reflection. In this case, two of them are seemingly opposite: the project (long - closed forward) and the reflection (long - reversed).

\footnotetext{
${ }^{41}$ Gycev C. C., Gyceva E. A. Vzaimodejctvie poznavatel'ny’x proczeccov v naychnom i texnicheckom tvorchectve. - Leningrad : Nayka, 1989. - $128 \mathrm{c}$.

${ }^{42}$ Gacparckij V. Prakceologicheckij analiz proektno-konctryktorckix razrabotok. - Mockva : Mir, 1978. 172 c.; Dzhonc Dzh. K. Metody’ proektirovaniya ; per. c angl. - Mockva : Mir, 1986. - 32 c.; Ditrix Ya. Proektirovanie i konctryirovanie. Cictemny'j podxod / Ya. Ditrix. - Mockva : Mir, 1981. - 456 c.; Keccidi F. X. Ot mira k logocy / F. X. Keccidi. - Mockva : My'cl', 1972. - 198 c.; Khill P. Nayka i ickycctvo proektirovaniya: metody' proektirovaniya, naychnoe obocnovanie reshenij. - Mockva : Mir, 1973. - $264 \mathrm{c}$.

${ }^{43}$ Dzhonc Dzh. K. Metody' proektirovaniya ; per. c angl. - Mockva : Mir, 1986. - 32 c.
} 
Thus, V.F. Cidorenko ${ }^{44}$ states as the genesis of a practicallytechnologically dedicated gene indicates that it is an intrinsically practically-technologically correct, if it is a present-day complex organized system of interaction of different facsimiles, functionally connected with the systems of management, planning and production, and, first, if it is a special kind of production of a fair documentation, in the language which is expected and desirable for the realization of the image of the future object - things that are notable areas, systems of activity and life.

\section{CONCLUSIONS}

But the direct-textual filter does not reduce itself only to an intrinsic direct-textual activity, and another source, K. М. Кантор, ${ }^{45}$ introducing detached practically-productive activity, if it is implemented in the true language of the boundary posterior and the value of the filter.

In this way, the relationship of projection with science, philosophy, coloring, art, technology, production, living, government and other social institutions and functional systems of activity must be deduced from the understanding of the fundamental cultural state of projection, its innovation, and cultural nature. In the sphere of coloring, the need for this potential and, as a result, the inclusion of direct-textured filters are the most important results for coloring, in our opinion, with the fact that the gradual extrusion of a nay-technocratic paradigm, a valuable-selfdetermination of the educators of a different priority of the humanitarian paradigm served a new estimate of the color of the octane, which would be responsible for the social ordering and needs of the occipital origin. The problem of forming a direct-technoculture is actual for a system of technological evaluation, as it is, basically, progressive meets the need for the formation of a new quality of human XXI century. - is life-giving and practically-oriented, culturally responsive and promotes the formation of social competency of objects of manifestation. In such a context, the direct-techno-logy can be defined as "socially-friendly, three-prong

\footnotetext{
${ }_{44}^{44}$ Cidorenko V. F. Genezic proektnoj kyl’tyry’ // Voprocy’ filocofii. - 1984. - № 10. - C. 86-99.

${ }^{45}$ Kantor K. M. Proektnoct' rycckoj kyl'tyry'. - Mockva, 1980. - 267 c.
} 
activity if at this there is a dialectical unity of the predetermination of priming (the formation of values, the norm, the sign system, etc.) and the decomposition (the estimation), aiming at the transformation of activity, which is the outlying point of view, to the transformation of the wealth of humanity into the inner wealth, or the secular detection and development of cynical forces, as it takes more and more of the projection of the objects.

Formation of a direct-technographic filter in such a comprehensible principle is impracticable without a valuable-aiming self-definition in humanitarian paradigm, insofar as it is recognized in its context as valid, it constitutes value propositions for the self-determination of any subject of pedagogical origin. And if in the result of paradigmatic self-determination in the context of the humanitarian paradigm, we will understand the point of manifestation as the process of person development in the shade of its formation, that the formation of a direct-technography, together with the traditional training, plays cytology in this process.

\section{REFERENCES}

1. Acmolov A. G. Pcixologiya lichnocti. - Mockva : MGU, 1980. $367 \mathrm{c}$.

2. America 2000: an Education Strategy. - V. S. Government printing office, 1991. $-66 \mathrm{p}$.

3. Arictotel. Cochynenyia v chetyrex tomax. - Tom 1: Metafyzyka / red. V. F. Acmyc. - Mockva : Mycl, 1975. - 550 c.

4. Arnoldov A. Y. Teoryia kyltyry: Yctoryzm y voprocy metodolohyy // Kyltyra, chelovek y kartyna myra. - Mockva : Nayka, 1987. - C. 5-27.

5. Axytin A. V. Ponyatie "priroda" v antichnocti i v Novoe vremya. Mockva : Nayka, 1988. - 208 c.

6. Ball G. A. Teoriya ychebny'x zadach. - Mockva : Pedagogika, 1990. $-184 \mathrm{c}$.

7. Bereziuk O.S. Metodyka poetapnoho upravlinnia protsesom modeliuvannia pedahohichnykh sytuatsii // Profesiina pedahohichna osvita: innovatsiini tekhnolohii ta metodyky: Monohrafiia / $\mathrm{Za}$ red. 
O. A. Dubaseniuk. - Zhytomyr : Vyd-vo ZhDU im. I. Franka, 2009. S. 377-390.

8. Born M. Fizika v zhizni moego pokoleniya. - Mockva : Izd-vo inoctrannoj literatyry', 1963. $-535 \mathrm{c}$.

9. Caimon H. Nayky ob yckycctvennom. - Mockva : Myr, 1972. $-147 \mathrm{c}$.

10. Cemenova N. N. Nayka kak yavlenye kyltyry // Nayka y ee mecto v kyltyre. - Novocybyrck : Nayka, Cyb. otdelenye, 1990. - C. 51-58.

11. Cerykov V. V. Obrazovanye y lychnoct. Teoryia y praktyka proektyrovanyia pedahohycheckyx cyctem. - Mockva : Lohoc, 1999. $-272 \mathrm{c}$.

12. Cheshev V. V. Vzaimocvyaz' inzhenernoj deyatel'nocti i naychnogo znaniya // Voprocy' filocofii. - 1986. - № 3. - C. 53-60.

13. Cidorenko V. F. Genezic proektnoj kyl'tyry' // Voprocy' filocofii. - 1984. - № 10. - C. 86-99.

14. Clactenyn V. A., Podymova L. C. Pedahohyka: Ynnovatsyonnaia deiatelnoct. - Mockva : Mahyctr, 1997. - C. 36.

15. Cydorenko V. F. Henezyc proektnoi kyltyry // Voprocy fylocofyy. -1984 . - № 10. - C. 86-99.

16. Ditrix Ya. Proektirovanie i konctryirovanie. Cictemny'j podxod. Mockva : Mir, 1981. $-456 \mathrm{c}$.

17. Dzhonc Dzh. K. Metody' proektirovaniya ; per. c angl. - Mockva : Mir, 1986. $-32 \mathrm{c}$.

18. Ekolohyia cheloveka: ocnovnye problemy. Cbornyk naychnyx trydov. - Mockva : Nayka, 1988. - 222 c.

19. Frydman L. M. Pedahohycheckyi opyt hlazamy pcyxoloha. Mockva : Procveshchenye, 1987. - 224 c.

20. Gacparckij V. Prakceologicheckij analiz proektno-konctryktorckix razrabotok. - Mockva : Mir, 1978. - $172 \mathrm{c}$.

21. Gineczinckij V. I. Ocnovy' teoreticheckoj pedagogiki : ychebnoe pocobie. $-\mathrm{CPb}$., 1992. $-325 \mathrm{c}$.

22. Goroxov V. G. Znat', chtoby' delat'. Ictoriya inzhenernoj profeccii i ee rol' v covremennoj kyl'tyre. - Mockva : Znanie, 1987. - $176 \mathrm{c}$. 
23. Gycev C. C., Gyceva E. A. Vzaimodejctvie poznavatel'ny'x proczeccov v naychnom i texnicheckom tvorchectve. - Leningrad : Nayka, 1989. - 128 c.;

24. Hershynckyi B. C. Fylocofyia obrazovanyia dlia XXI veka: (V poyckax praktyko-oryentyrovannyx obrazovatelnyx kontseptsyi. Mockva : Covershenctvo, 1998. - 608 c.

25. Hershynckyi B. C. Fylocofyia obrazovanyia: naychnyi ctatyc y zadachy // Covetckaia pedahohyka. - 1991. - № 4. - C. 69-74;

26. Holocovker Ya. Э. Lohyka myra. - Mockva : Nayka, 1987. - 218 c.

27. Kantor K. M. Opyt cotsyalno-fylocofckoho obiacnenyia proektnyx vozmozhnoctei dyzaina // Voprocy fylocofyy. - 1981. - № 11. - C. 84-97.

28. Kantor K. M. Proektnoct' rycckoj kyl'tyry'. - Mockva, 1980. $267 \mathrm{c}$.

29. Keccidi F. X. Ot mira k logocy. - Mockva : My'cl', 1972. - 198 c.

30. Kharitonovich D. E'. Izobretatel'ctvo i rannie formy' inzhenernoj deyatel'nocti // Voprocy' filocofii. - 1985. - № 2. - C. 91-102.

31. Khill P. Nayka i ickycctvo proektirovaniya: metody' proektirovaniya, naychnoe obocnovanie reshenij. - Mockva : Mir, 1973. $264 \mathrm{c}$.

32. Khiucen T. Obrazovanye v 2000-m hody: yccledovatelckyi proekt ; per. co shved. E. M. Cokolova. - Mockva : Prohrecc, 1977. - 343 c.

33. Kolmogorova L. C. Vozractny'e vozmozhnocti i ocobennocti ctanovleniya pcixologicheckoj kyl'tyry' shkol'nikov : dicc. ... d-ra pcixol. nayk. - Mockva, 2002. - 425 c.

34. Kyliutkyn Yu. N., Cyxobckaia H. C. Modelyrovanye pedahohycheckyx cytyatsyi. - Mockva : Pedahohyka, 1981. - 207 c.

35. Kyzmyna N. V. Ocherky pcyxolohyy tryda ychytelia: pcyxolohycheckaia ctryktyra deiatelnocty ychytelia y formyrovanye eho lychnocty. - Lenynhrad : LHU, 1967. - 184 c.

36. Kyzmyna N. V., Hynetsynckyi V. Y. Aktyalnye problemy profeccyonalno-pedahohycheckoi podhotovky ychytelia // Covetckaia pedahohyka. - 1982. - № 3. - C. 63-66. 
37. Locev A. F. E'ctetika Vozrozhdeniya. - Mockva : Ickycctvo, 1978. - 495 c.

38. Novikov A. M., Novikov D. A. Metodologiya. - Mockva : CINTEG, 2007. $-668 \mathrm{c}$.

39. Nychkalo N.H. Rozvytok profesiinoi osvity $\mathrm{v}$ umovakh hlobalizatsiinykh ta intehratsiinykh protsesiv: monohrafiia. - K.: Vydavnytstvo NPU imeni M.P. Drahomanova, 2014. - $125 \mathrm{~s}$.

40. Nykytyn V. A. Orhanyzatsyonnye typy covremennoi kyltyry : avtoreferat doktora kyltyrolohyy : 24.00.01 - teoryia kyltyry. - Toliaty Mockva, 1998. - 49 c.

41. Onyshkyn V. H., Kyliutkyn Yu. N. Nepreryvnoe obrazovanye pryorytetnoe napravlenye nayky // Covetckaia pedahohyka. - 1989. № 2. - C. 86-91.

42. Rozin V. M. Cpeczifika i formirovanie ectectvenny'x, texnicheckix i gymanitarny'x nayk. - Kracnoyarck : Izd-vo Kracnoyarckogo yn-ta, 1989. - 200 c.

43.Zahviazynckyi V. Y. Pedahohycheckoe tvorchectvo ychytelia. Mockva : Pedahohyka, 1987. - $160 \mathrm{c}$.

44. ЮНЕСКО и развитие образования взрослух // Перспектива. Вопросу образования. - 1982. - № 1-2. - С. 137-145.

\section{Information about the authors:} Slabko V. M.,

Doctor of Pedagogical Sciences, Head of the Department of Adult Education at the Faculty National Pedagogical Dragomanov University 9, Pyrohova str., 01601, Kyiv, Ukraine

Makarenko L. L.,

Doctor of Pedagogical Sciences, Professor, Professor of Department of the Informative Systems and Technologies National Pedagogical Dragomanov University 9, Pyrohova str., 01601, Kyiv, Ukraine 